\title{
Research
}

\section{Ecosystem Services, Land-Cover Change, and Stakeholders: Finding a Sustainable Foothold for a Semiarid Biodiversity Hotspot}

\author{
$\underline{\text { Belinda Reyers }}^{1}, \underline{\text { Patrick J. O'Farrell }}^{1}$, Richard M. Cowling ${ }^{2}$, Benis N. Egoh ${ }^{3}$, David C. Le Maitre ${ }^{1}$, and \\ Jan H. J. Vlok ${ }^{4}$
}

\begin{abstract}
Land-cover change has been identified as one of the most important drivers of change in ecosystems and their services. However, information on the consequences of land cover change for ecosystem services and human well-being at local scales is largely absent. Where information does exist, the traditional methods used to collate and communicate this information represent a significant obstacle to sustainable ecosystem management. Embedding science in a social process and solving problems together with stakeholders are necessary elements in ensuring that new knowledge results in desired actions, behavior changes, and decisions. We have attempted to address this identified information gap, as well as the way information is gathered, by quantifying the local-scale consequences of land-cover change for ecosystem services in the Little Karoo region, a semiarid biodiversity hotspot in South Africa. Our work is part of a stakeholder-engaged process that aims to answer questions inspired by the beneficiaries and managers of ecosystem services. We mapped and quantified the potential supply of, and changes in, five ecosystem services: production of forage, carbon storage, erosion control, water flow regulation, and tourism. Our results demonstrated substantial (20\%-50\%) declines across ecosystem services as a result of land-cover change in the Little Karoo. We linked these changes in land-cover to the political and land-use history of the region. We found that the natural features that deliver the Little Karoo's ecosystem services, similar to other semiarid regions, are not being managed in a way that recognizes their constraints and vulnerabilities. There is a resulting decline in ecosystem services, leading to an increase in unemployment and vulnerability to shocks, and narrowing future options. We have proposed a way forward for the region that includes immediate action and restoration, mechanisms to fund this action, the development of future economic activity including tourism and carbon markets, and new ways that the science-stakeholder partnership can foster these changes. Although we acknowledge the radical shifts required, we have highlighted the opportunities provided by the resilience and adaptation potential of semiarid regions, their biodiversity, and their inhabitants.
\end{abstract}

Key Words: carbon; grazing; human well-being; land degradation; ostriches; tourism; trade-offs; water.

\section{INTRODUCTION}

The last few centuries have seen significant changes in the world's ecosystems, tracking our efforts to: enhance the production of food, fiber, and fuel; control water supplies; and reduce our exposure to natural dangers like predators and storms (Kareiva et al. 2007, Swinton et al. 2007). These efforts have resulted in improvements in the global aggregate of human well-being, with incomes, population sizes, life expectancies, and food supplies showing substantial increases in most parts of the world
(Levy et al. 2005). Although the immediate benefits for humans are clear, the ecosystem changes wrought have far-reaching consequences for current and future human well-being (Millennium Ecosystem Assessment (MA) 2005). Understanding these consequences requires an awareness and assessment of the links between ecosystems, their biodiversity, and human well-being. These are mediated through ecosystem services, i.e., the benefits humans obtain from ecosystems (MA 2003).

\footnotetext{
${ }^{1}$ Natural Resources and the Environment, Council for Scientific and Industrial Research, ${ }^{2}$ Department of Botany, Nelson Mandela Metropolitan University, ${ }^{3}$ Centre for Invasion Biology, Department of Botany and Zoology, Stellenbosch University, ${ }^{4}$ Regalis Environmental Services
} 
Ecosystems provide bundles of ecosystem services that interact with one another in a dependent and nonlinear fashion (Pereira et al. 2005, van Jaarsveld et al. 2005). Decisions to exploit a particular ecosystem service affect the type, magnitude, and mix of services provided by that ecosystem (De Fries et al. 2004, Rodríguez et al. 2006, Bennett and Balvanera 2007). For example, a decision to cultivate an area of land and grow a crop may yield more production services in the form of food or fiber, but can impair the regulatory service of soil retention, decrease the service of water quality regulation, and contribute to eutrophication of aquatic habitats. Ecosystem service trade-offs may have negative consequences for the people dependent on them, and together with the associated erosion of biodiversity, can ultimately undermine the ecosystem service being optimized. The MA presented evidence of the trade-offs being made in the global bundle of ecosystem services and human well-being (MA 2005). It demonstrated that over the past 50 years, enhancements in four of the 24 ecosystem services assessed by the MA (crop production, livestock production, aquaculture, and carbon sequestration) have largely come at a cost to 15 other services assessed (mostly regulating and supporting services). The MA concluded that many of these declines are characteristically nonlinear and abrupt, impact the poorest people, and are often a cause of poverty.

Changes in ecosystems and their services are caused by multiple interacting direct drivers (e.g., landcover change, climate change, irrigation, or alien invasive species), which in turn are controlled by indirect drivers (e.g., demographic, economic, or cultural changes) (MA 2003). Land-cover change has been highlighted as one of the most important direct drivers of terrestrial ecosystem change (Vitousek et al. 1997, MA 2005). Land-cover change involves changes in the human management of ecosystems (e.g., settlement, cultivation, and grazing) that alter the biogeochemical cycles, climate, and hydrology of an ecosystem. It also drives biodiversity loss through habitat fragmentation and destruction. Land-cover change includes the outright conversion of an area from one land use to another (hereafter referred to as "land transformation"), as well as declines in the biological or economic productivity and complexity of the land as a result of land use or processes related to human activity (hereafter referred to as "land degradation").

Apart from the work of the MA and its subglobal assessments (Pereira et al. 2005), the consequences of land-cover change for ecosystem services and human well-being have received limited attention at a local scale. Studies are largely descriptive and focus on the trade-offs associated with the optimization of a provisioning service, particularly those services associated with agricultural production (Foley et al. 2005, Bohensky et al. 2006, Rodríguez et al. 2006). Most note qualitative declines in regulating and supporting services, as well as in biodiversity. The few quantitative localscale studies that have been carried out rely on landcover change data (derived from remote sensing) and ecosystem service value coefficients (usually extracted from Costanza et al. 1997) to calculate changes in ecosystem service values over time (Kreuter et al. 2001, Zhao et al. 2004, Viglizzo and Frank 2006, Li et al. 2007). Case studies and simulations of land-cover change have also been used to examine the effects on single ecosystem services or processes (e.g., nitrogen levels (Turner et al.2003), pollination (Priess et al. 2007), livestock production services (O'Farrell et al. 2007), or soil organic carbon (Yadav and Malanson 2008)). The paucity of information on the consequences of landcover change across multiple ecosystem services, especially at the scale at which management decisions are made, presents a significant obstacle to understanding and managing ecosystems and their services (De Fries et al. 2004).

A further obstacle on this path to sustainable ecosystem management is the process by which information is often derived and used. Many scientists concerned with the complex problems of sustainable development have highlighted that if our final objectives are to foster informed decision making; transform attitudes, behavior, and institutions; and develop appropriate capacity, competencies, and ownership, then the way we conduct our science needs to change (Mitchell et al. 2004, Max-Neef 2005, Hadorn et al. 2006, Knight et al. 2008). They argue that the traditional method of science as a simple research process that provides a solution needs to change to one where science is a social process aimed at resolving a problem through the participation and mutual learning of stakeholders.

With this in mind, we aim to develop information on the local-scale consequences of land-cover change across multiple ecosystem services. We propose to: (1) quantify and map ecosystem services; (2) assess the distribution of ecosystem services, areas of importance to service delivery, and areas of overlap between services; and (3) assess 
changes in ecosystem service delivery as a result of past land-cover change.

Our research has adopted a method that embeds the ecosystem service assessment in a social process aimed at identifying and implementing strategies for enhancing and safeguarding ecosystem service delivery. The components reported here belong to the assessment phase of this process and will feed into the subsequent planning and management phases outlined by Cowling et al. (2008). The assessment is a structured process that provides knowledge useful for decision makers and managers. It aims to answer questions inspired by the beneficiaries and managers of ecosystem services, providing knowledge useful for mainstreaming ecosystem services into local landuse planning.

Below we detail the study area and its stakeholders, describe the assessment process, present our results, and then discuss their implications for the Little Karoo region and its future. We end with some thoughts on how scientists and stakeholders can build a more sustainable future for the Little Karoo.

\section{METHODS}

\section{Study Area: Geography}

The Little Karoo region (ca. $19000 \mathrm{~km}^{2}$ ) is a semiarid, intermontane basin where vegetation associated with three globally recognized biodiversity hotspots intersects and intermingles (hotspots include the Succulent Karoo, MaputalandPondoland-Albany, and Cape Floristic Region (Mittermeier et al. 2005)). These hotspots are recognized by their high numbers of plant species (especially endemic species), as well as by the significant threats facing these species. Altitude ranges from 400 to $>1500 \mathrm{~m}$ a.s.l. This plays a major role in determining rainfall, which varies from $<200$ $\mathrm{mm}$ to $>1200 \mathrm{~mm}$ at high altitudes. High levels of solar radiation $(>80 \%)$ together with variable rainfall result in potential evapotranspiration of $>10$ times the rainfall $(2250 \mathrm{~mm} / \mathrm{yr})$. Mean annual runoff is only $6 \%$ of the rainfall and is highly variable, being dominated by episodic flood flows in seasonal systems. The Little Karoo, similar to other semiarid regions of the world, is a region of overall water scarcity. Current demand already exceeds the sustainable supply from dams in the Gouritz River basin, and irrigation uses $90 \%$ of the water available
(Le Maitre and O'Farrell 2008). The high mountains are of erosion-resistant and highly fractured Table Mountain Group sandstone. They form critical groundwater recharge areas and are the source of most of the perennial rivers and streams in the area.

O'Farrell et al. (2008) present a detailed history of the region's land use and highlight that the major form of land use has been, since the 1730s, extensive grazing and browsing by livestock (chiefly ostriches, but also sheep and goats). Very little $(<10 \%)$ outright transformation of natural habitat to cultivated areas has taken place. This has been limited to areas with shale-derived soils and sufficient rain for dryland cultivation, and alluvial habitats with access to irrigation water (Fig. 1; Thompson et al. 2009). However, degradation of vegetation and soil through overgrazing is the main driver of land-cover change and biodiversity loss in the area. Historical records indicate that certain districts in this region have been heavily overstocked by cattle, horses, donkeys, sheep, goats, and ostriches (Dean and Milton 2003), leaving large areas $(52 \%)$ of degraded land in the Little Karoo (Thompson et al. 2009). Rouget et al. (2006) and Gallo et al. (2009) demonstrate that degradation and clearing for croplands have resulted in a $35 \%$ decline in biodiversity condition in the Little Karoo, and $20 \%$ of the area being recognized as threatened ecosystems.

The high biodiversity value of the area, along with the pressures on this biodiversity, have resulted in the Little Karoo being identified as an area of conservation importance by three internationally funded conservation and development programs (the Cape Action Plan for People and the Environment, the Subtropical Thicket Ecosystem Program, and the Succulent Karoo Ecosystem Plan), each of which identified a suite of projects for achieving conservation-related objectives in the Little Karoo.

\section{Study Area: Governance and Stakeholder Environments}

Environmental governance in South Africa is complex, spanning many sectors as well as national, provincial, and local spheres of government. Although national and provincial governments have concurrent legislative competence for environmental management, it is at the local municipal scale that land and natural resource use decisions are made 
Figure 1. Study area of the Little Karoo illustrating its position in South Africa, as well as the current land-cover situation.

Note: Transformed areas are those that have been converted to cropland and urban areas. Distinction is drawn between areas of moderate and severe degradation where the former can be restored with the removal of grazing pressure, whereas the latter will require restoration actions to restore the plant communities. The map is transposed over a digital elevation model for illustrative purposes.

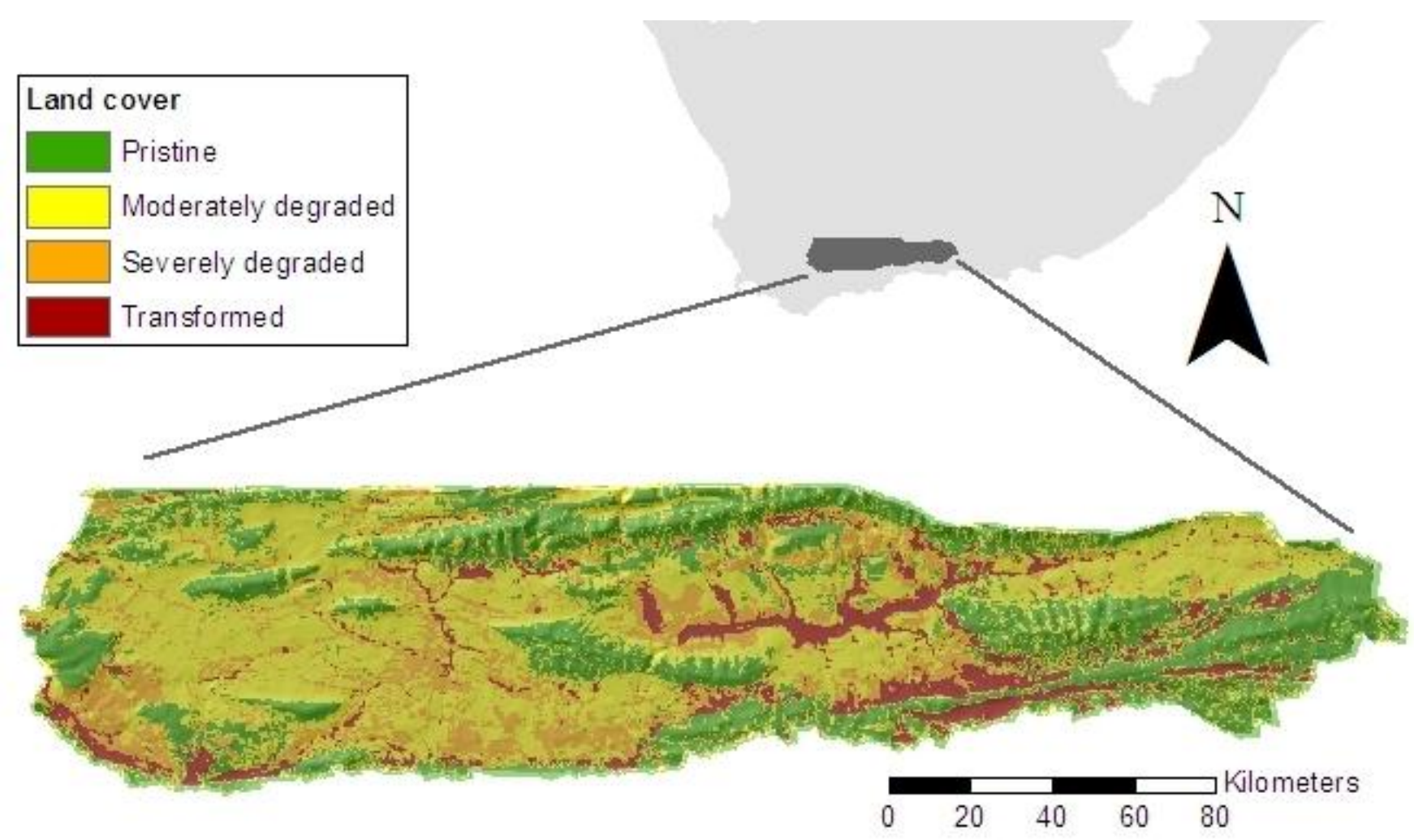

Thompson et al. 2008

and implemented (Pierce et al. 2005). The Little Karoo encompasses portions of five local municipalities. Despite some innovative legislation, institutions, and processes, as well as budgetary increases, capacity and finances still appear to be insufficient to meet the demands of the crosscutting cooperative governance required for environmental management (Department of Environmental Affairs and Tourism 2006). This is particularly the case at provincial and municipal levels and remains a major obstacle to achieving sustainable development targets.

In recognition of the significant conservation challenges and the concurrent governance challenges facing the region, the Gouritz Initiative (GI) was established. It was set up in 2003 in order to coordinate strategies, facilitate co-governance, build capacity through mutual learning, and accommodate the needs of a diverse array of stakeholders. Its mission is to "...take ownership of the sustainable utilization of the unique biodiversity of the area by ensuring global recognition through partnerships, continuous awareness and responsible decision making for the benefit of all people, now and in the future."

The GI is coordinated by a steering committee with representation from all key partners including government departments, landowners, non- 
governmental organizations, and municipalities. There is also a GI Forum where a larger number of stakeholders (including landowners, business representatives, and scientists) meet and discuss issues of concern. Under the auspices of the GI, the Little Karoo Study Group was established to undertake research identified as important by the GI Forum. This study group comprises eight research institutions and five implementing agencies collaborating on research projects to support and promote sustainable development and the wise use of ecosystem services in the Little Karoo.

This study has arisen from the interaction between the GI Forum and the Little Karoo Study Group, precipitated by concerns expressed in the GI Forum around: the increase in the extent and intensity of degradation of the land by increased livestock (particularly ostrich) numbers (O'Farrell et al. 2008); concerns about flood damage (Eden District Municipality 2008); problems regarding water security and intentions to mine fossil water (Le Maitre et al. 2007); and the increasing importance of tourism as an economic sector. The stakeholder forum requested the study group to conduct an assessment of the natural features (ecosystem services) that support the ostrich and tourism industries, as well as those that regulate floods and water supplies. This assessment would form the first step of a stakeholder forum exercise to identify opportunities and constraints in working toward a sustainable future.

\section{Assessment: Mapping Potential Ecosystem Services}

The Little Karoo has been the site of much research in the last few years, which has resulted in some key databases essential to the study of ecosystem services (Vlok et al. 2005, Le Maitre et al. 2007, O'Farrell et al. 2008, Thompson et al. 2009). Of particular value to this study is a map of vegetation types mapped at a 1:50 000 scale (Vlok et al. 2005). This map was developed in order to inform decision making about conservation, sustainable commercial farming, and land-use planning matters in the region. Accordingly, it mapped 369 vegetation units on the basis of their floristic composition. The vegetation units were classified into 32 habitat types relevant to the agricultural and wildlife industries in the region, by considering their physiognomy as well as the floristic component of the vegetation units (Vlok et al. 2005). The habitat types are nested within six biomes: Subtropical Thicket, Succulent Karoo, Renosterveld, Fynbos, Aquatic Drainage, and Aquatic Source.

The spatial extent of land transformation and degradation of the Little Karoo has also been mapped at a 1:50 000 scale (Fig. 1; Thompson et al. 2009). This map depicts areas of pristine vegetation and transformed (cultivated and urban) areas, and importantly, it also maps moderately and severely degraded areas. Moderately degraded areas are those areas where, although the plant communities have been impacted by grazing, this impact is limited mainly to the trampling and degradation of biotic crusts, some soil loss, and declines in the populations of palatable species. Removal of grazing pressure would allow these communities to return to a near pristine state. In contrast, severely degraded areas have been substantially overgrazed and have no biological soil crusts, severe soil loss, and totally altered plant communities (complete loss of palatable species). These areas require restoration actions to re-establish the communities and ecosystem function. The four categories of land cover (pristine, moderately degraded, severely degraded, and transformed) will have different consequences for the ecosystem services provided by a parcel of land. As the land-cover data were only available for 2005, our analyses are based on the difference between the 2005 data and the precolonial condition where all areas are assumed to be pristine (Scholes and Biggs 2005).

Our work is based on a suite of ecosystem services identified by the GI Forum as being of importance in this area. Carbon storage was not identified by the forum, but was included based on the potential opportunities it presents for restoration activities (Mills and Cowling 2006). The five services we have examined are: (1) production of forage for domestic livestock; (2) carbon storage; (3) erosion control; (4) freshwater flow regulation; and (5) tourism.

Rationales and descriptions of each ecosystem service are presented below (details on the methods used to map the services are available in Appendix 1). We first map the potential delivery of ecosystem services, presuming all areas are pristine. When mapping the ecosystem services and assessing the consequences of land-cover change, we relied on a diversity of available data sources ranging from peer-review literature to expert consultation. This reliance on available and diverse data has important 
implications when interpreting the findings of this study. In outlining the methods used in Appendix 1, we follow the procedure of the MA by assigning levels of certainty to each ecosystem service map based on the type and amount of data, as well as the strength of review or consensus.

\section{Potential forage production}

Livestock production is the most important economic activity and employer in the Little Karoo, although its economic importance has declined (Le Maitre and O'Farrell 2008). Forage production is defined as the provision of forage for grazing rangeland livestock. We mapped this as hectares required per large stock unit (LSU) per habitat type.

\section{Potential carbon storage}

The Little Karoo includes components of the Subtropical Thicket biome, which is particularly vulnerable to overgrazing (Hoffman and Cowling 1990); in fact, overgrazing has left $19.6 \%$ and $62.1 \%$ of the biome in the Little Karoo severely and moderately degraded, respectively (Thompson et al. 2009). Of relevance to this study is that the biome shows unusually high rates of carbon sequestration (Mills et al. 2005) and demonstrates significant potential for restoration through the use of carbon credits and other payments for ecosystem services (Mills and Cowling 2006). This ecosystem service was mapped as tons of carbon stored per hectare per habitat type.

\section{Potential erosion control}

The weather patterns in this area (most notably the cutoff lows) result in frequent floods, which have an enormous impact on the region's economy (Eden District Municipality 2008). Overgrazing and subsequent degradation have resulted in increases in surface runoff, changes in flow and groundwater regimes, decreases in water quality, and increases in the severity and frequency of floods (Le Maitre et al. 2007). Natural ecosystems play a vital role in ameliorating these impacts by retaining soils and preventing soil erosion. The ecosystem service of erosion control depends mainly on the structural aspects of ecosystems (especially vegetation cover and root systems) and includes the protection of the soil, as well as the maintenance of water quality in nearby water bodies (de Groot et al. 2002). Areas requiring this service are those vulnerable to erosion, as determined by the rainfall, soil depth, and texture. We have mapped this vulnerability as areas of high, medium, and low erosion hazard. The former corresponds with areas where natural vegetation cover must be maintained to control erosion.

\section{Potential water-flow regulation}

The Little Karoo is a water-limited environment with water availability restricting rangeland production, as well as dryland and irrigated farming, which are the basis of the economy (Le Maitre and O'Farrell 2008). A number of previous studies have used the volume of water as a measure of the service of water provision (van Jaarsveld et al. 2005, Chan et al. 2006), but we have used a narrower definition because the volume is largely a function of the amount and distribution of rainfall (Bosch and Hewlett 1982, Calder 1998). We focus on two distinct and interlinked roles the ecosystem plays in the service of water provision: water-flow regulation and water-quality regulation (de Groot et al. 2002). The ecosystem service was mapped as millions of cubic meters of groundwater recharge per $1-\mathrm{km}^{2}$ grid cell.

\section{Potential tourism}

Tourism is becoming increasingly important in this region, and many landowners are turning to accommodation and recreational opportunities on their land as alternative income sources. The region is popular for its wide open spaces and scenery. This ecosystem service was mapped as areas that tourists can see from the major tourist driving routes, which are important to maintain in an attractive form for tourists.

\section{Assessment: Service Distribution, Overlap, and Change}

The maps of ecosystem services were evaluated in terms of their area of production and overlap with one another. For the purposes of display and comparison, each map of ecosystem services was classified into high, medium, and low production classes. For the continuous variable maps of carbon storage, forage production, and water-flow regulation, the classes were determined using a Jenks natural breaks classification in ArcGIS $₫ 9.2$ (Environmental Systems Research Institute 2008). For the erosion control and tourism maps, all areas of high erosion hazard and areas of viewshed were 
included as high production areas, respectively. Overlap was assessed between high production areas (hereafter referred to as service hotspots (following Egoh et al. (2008)) and was measured using proportional overlap (Prendergast et al. 1993), which measures the area of overlap as a percentage of the smallest hotspot. An assessment of ecosystem service condition was conducted by analyzing the percentage of the four categories of land cover (pristine, moderately degraded, severely degraded, and transformed) within each ecosystem service hotspot.

To convert land-cover statistics into measures of ecosystem service change, we developed a matrix of the extent to which the transformed and degraded categories of land cover diminished the delivery of each of the quantified ecosystem services. Estimates were based on expert knowledge for forage production and freshwater-flow regulation, and a mix of expert knowledge and literature sources for carbon storage (Mills et al. 2005). This was done at the habitat level for the services of forage production and carbon storage, and at the biome level for waterflow regulation. Appendix 2 shows the ecosystem service values per habitat type and land-cover category for forage production and carbon storage. Appendix 3 shows the values for water-flow regulation per biome. The values were reviewed by relevant experts, and we have assigned a medium certainty to the matrix due to limited empirical data. We assumed that cultivated and urban areas could not reliably provide these services. We acknowledge the flaws in this assumption as these areas are able to produce some levels of services (see Colding et al. 2006); however, we were unable to determine the residual service amounts provided by these areas and, therefore, assumed them to be zero.

Using a GIS, we calculated the amount of each ecosystem service (forage production, carbon storage, and water-flow regulation) provided under current land-cover conditions by multiplying the area of each habitat type or biome within each landcover category by the values listed in Appendices 2 and 3. For the services of erosion control and tourism, we calculated the area of high erosion control and viewsheds in pristine or moderately degraded land-cover categories and assumed that only these areas could provide the services currently. We converted the changes in each ecosystem service into proportions of the potential service in order to make the changes comparable; we used the values to develop spider diagrams (such as those used in MA 2003, De Fries et al. 2004, and Rodríguez et al. 2006) to depict the changes in ecosystem service supply.

\section{RESULTS}

\section{Potential Ecosystem Services in the Little Karoo}

Figure 2 shows the distribution of the potential supply of five ecosystem services and the service hotspots in the Little Karoo. Table 1 presents the extent of service hotspots and overlap between hotspots across services. It is clear that high levels of supply of ecosystem services are limited to a few areas; service hotspots occupy only $10 \%-38 \%$ of the region. Water-flow regulation, erosion control, and carbon storage have particularly small service hotspots (Table 1). Furthermore, there appears to be limited congruence between service hotspots with proportional overlap $<40 \%$, with the exception of forage production and erosion control, which share $76 \%$ of their hotspots (Table 1). Carbon storage shares no hotspots with erosion control and very little $(0.04 \%)$ with water-flow regulation. The larger service hotspots of tourism and forage production show the highest congruence with other ecosystem service hotspots.

Forage production and carbon storage, although both produced in lowland areas, are associated with different biomes: the former is spread across the Thicket, Succulent Karoo, and Renosterveld biomes, whereas the latter is found in the central and eastern Thicket areas. Areas of importance to erosion control are located in both montane and lowland areas in regions of high runoff (source) and run-on (drainage) areas, as well as in the Gannaveld vegetation (a vegetation type of high forage production) of the Little Karoo. Areas with high groundwater recharge, and thus the sources of sustained river flows, are limited to the mountains and concentrated at elevations higher than $1000 \mathrm{~m}$ a.s.l. Areas of importance to tourism are determined by a combination of topography and road networks and are primarily found in the central regions and along mountain passes. 
Figure 2. Maps of potential ecosystem services of the Little Karoo illustrating: (a) Forage production: number of hectares required by a large stock unit (LSU) in each habitat type; (b) Carbon storage: tons of carbon stored per hectare of each habitat type; (c) Water-flow regulation: volume of water provided by a 1-km² grid; (d) Erosion control: areas of high, medium, and low erosion hazard requiring the maintenance of natural vegetation cover; and (e) Tourism: 10-km viewshed seen by tourists from the major tourist routes.

Note: All maps are transposed over a digital elevation model for illustrative purposes.
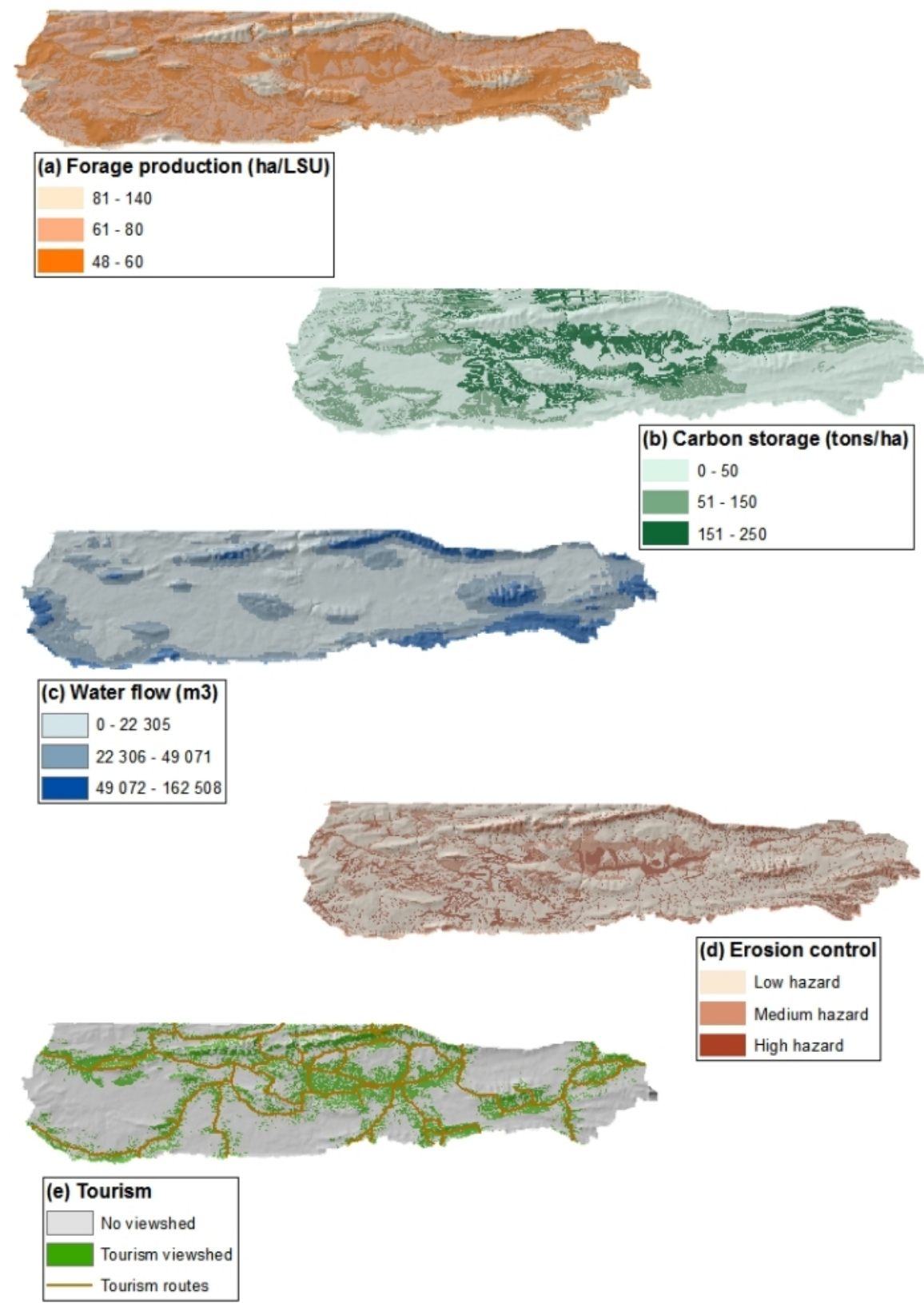
Table 1. Extent and proportional overlap of ecosystem service hotspots.

\begin{tabular}{|c|c|c|c|c|c|}
\hline \multirow{2}{*}{$\begin{array}{l}\text { Ecosystem } \\
\text { service }\end{array}$} & \multicolumn{4}{|c|}{ Proportional overlap between ecosystem service hotspots } & \multirow{2}{*}{$\begin{array}{l}\text { Hotspot area } \\
\text { (\% of study area) }\end{array}$} \\
\hline & Carbon & Erosion & Water & Tourism & \\
\hline Forage & 21.52 & 76.37 & 29.70 & 39.46 & 37.84 \\
\hline Carbon & & 0.00 & 0.04 & 33.85 & 16.64 \\
\hline Erosion & & & 13.08 & 25.30 & 14.50 \\
\hline Water & & & & 33.44 & 10.82 \\
\hline Tourism & & & & & 29.39 \\
\hline
\end{tabular}

\section{Ecosystem Services Changes in the Little Karoo}

Table 2 illustrates the land-cover situation in each of the five ecosystem service hotspots. Carbon storage and erosion control have very little of the service hotspots remaining in a pristine condition (12\% and 20\%, respectively). Water-flow regulation hotspots include the highest proportion of pristine land cover $(81 \%)$, followed by forage production $(41 \%)$ and tourism (39\%). Moderately degraded areas cover approximately one-third of all ecosystem service hotspots, with the exception of water production (4\%) and carbon storage (74\%). Erosion control hotspots have been $26 \%$ transformed.

The large proportion of the study region and ecosystem service hotspots that are currently transformed or degraded (Fig. 1, Table 2), as well as the changes in ecosystem services caused by landcover changes (Appendices 2, 3), result in large declines across all ecosystem services (Fig. 3). Compared with potential service supply, erosion control shows the largest declines (44\% of the erosion control hotspot had lost its vegetation cover), followed by forage production, carbon storage, and tourism viewsheds $(25 \%, 27 \%$, and $28 \%$ reductions in LSU, area attractive to tourists, and tons of carbon, respectively). Water-flow regulation shows the smallest decline $(18 \%)$ in potential volume of the sustained flows. The services showing greatest declines are those delivered by the lowland and foothill regions that have been transformed to cultivated areas or overgrazed and subsequently severely degraded.

\section{DISCUSSION}

\section{Service Declines, Degradation, and Increasing Vulnerability in the Little Karoo}

Our work highlights the substantial impact of landcover change on ecosystem services in the Little Karoo, resulting in declines ranging from $18 \%-44 \%$ in ecosystem service levels. These declines mirror biodiversity losses in the region found by Rouget et al. (2006) and Gallo et al. (2009). Of particular concern to the region's future sustainability is the $18 \%$ decline in the water-flow regulating service and the $44 \%$ decline in areas responsible for erosion control. The significance of these declines relates to the semiarid nature of the Little Karoo, as well as the overarching role regulating services play in soil conservation and nutrient cycling, and in turn, the services of primary production and water provision (Safriel et al. 2005). It is the latter services that underpin the agricultural economy of semiarid systems like the Little Karoo.

These results also point to the substantial impacts of the extensive areas of degraded land. Degraded areas, which make up 52\% of the region, overlap with more than $40 \%$ of the hotspots of the carbon, forage, erosion, and tourism services. Overgrazing of these areas, together with clearing of other areas 
Table 2. Land-cover composition of ecosystem service hotspots shown as a percentage of the total hotspot.

\begin{tabular}{llllll}
\hline \hline & \multicolumn{2}{l}{ Ecosystem service hotspot } & & \\
Landcover category & Forage & Carbon & Erosion & Water & Tourism \\
\hline Pristine & $\mathbf{4 0 . 9 5}$ & 12.40 & 19.76 & $\mathbf{8 1 . 2 6}$ & $\mathbf{3 9 . 4 1}$ \\
Moderate & 31.75 & $\mathbf{7 3 . 9 9}$ & $\mathbf{3 6 . 0 0}$ & 4.42 & 33.32 \\
Severe & 11.17 & 10.22 & 18.36 & 6.45 & 12.83 \\
Transformed & 16.12 & 3.38 & 25.88 & 7.87 & 14.43 \\
& & & & & \\
\hline
\end{tabular}

Note: Bold values indicate the highest value per service.

to grow livestock feed to supplement the forage production service, have been major drivers of change in ecosystem services in the Little Karoo.

The declines in what are mostly regulating and supporting services, together with the documented biodiversity losses, raise concerns about long-term decreases in the region's productivity and resilience, and thus increases in its vulnerability to shocks such as floods, drought, or market shifts. It is evident that past land-use decisions have driven the Little Karoo into a tight corner. The region is facing decreased ecosystem service levels, threatened biodiversity, high unemployment levels, and narrowing future options. The situation mirrors semiarid regions around the world, which house the most vulnerable people, ecosystems, and ecosystem services (MA 2005).

Understanding the drivers of changes in land cover and subsequently in ecosystem services is essential in the design of interventions. Below, we reflect on the history of land use in the Little Karoo in an effort to extract key drivers of change for the purposes of potential intervention.

\section{Building a Sustainable Future: Understanding Drivers of Change}

The political, social, economic, and technological changes associated with the colonial period (16521910), as well as the Union and Apartheid eras (1910-1994), were key drivers of change in the
Little Karoo. These changes caused a switch from a system of transhumance pastoralism and subsistence farming to one of permanent commercial agriculture (O' Farrell et al. 2008). Of particular relevance are two major changes in land use that took place in the $1800 \mathrm{~s}$. The first was the beginning of ostrich farming in the region, and the second was the proclamation of nutrient-poor, montane areas as protected water catchments in the 1870s (Beinart 2003). Ostrich farming had negative and ongoing repercussions for the region's ecosystem services, and the protection of important water catchment areas helped to limit transformation and overgrazing.

The ostrich industry in the Little Karoo was initiated in the early to mid 1800s for the production of feathers. Over the next two centuries, the numbers of birds in the Little Karoo fluctuated radically due to outbreaks of avian diseases and changes in fashion and tastes. The deregulation of the industry in 1996, along with growing demand for ostrich meat, resulted in a dramatic increase in the number of ostriches. Census estimates for 2002 included 250 000 birds sales and 150000 birds on farms in the Little Karoo. These ostrich numbers alone total more than five times the total potential capacity of 27000 LSU in the Little Karoo (Fig. 2a; one ostrich $=0.35 \mathrm{LSU})$. This situation typifies current agricultural practices in the region, which have shifted away from traditional crop and livestock production to the production of ostriches and their main feed, lucerne. Ostriches have a significant impact on rangeland vegetation because they pull 
Figure 3. Changes in ecosystem service supply shown as a percentage of the potential service produced in the Little Karoo.

Note: The data labels show the current levels of ecosystem services as a percentage of the potential.

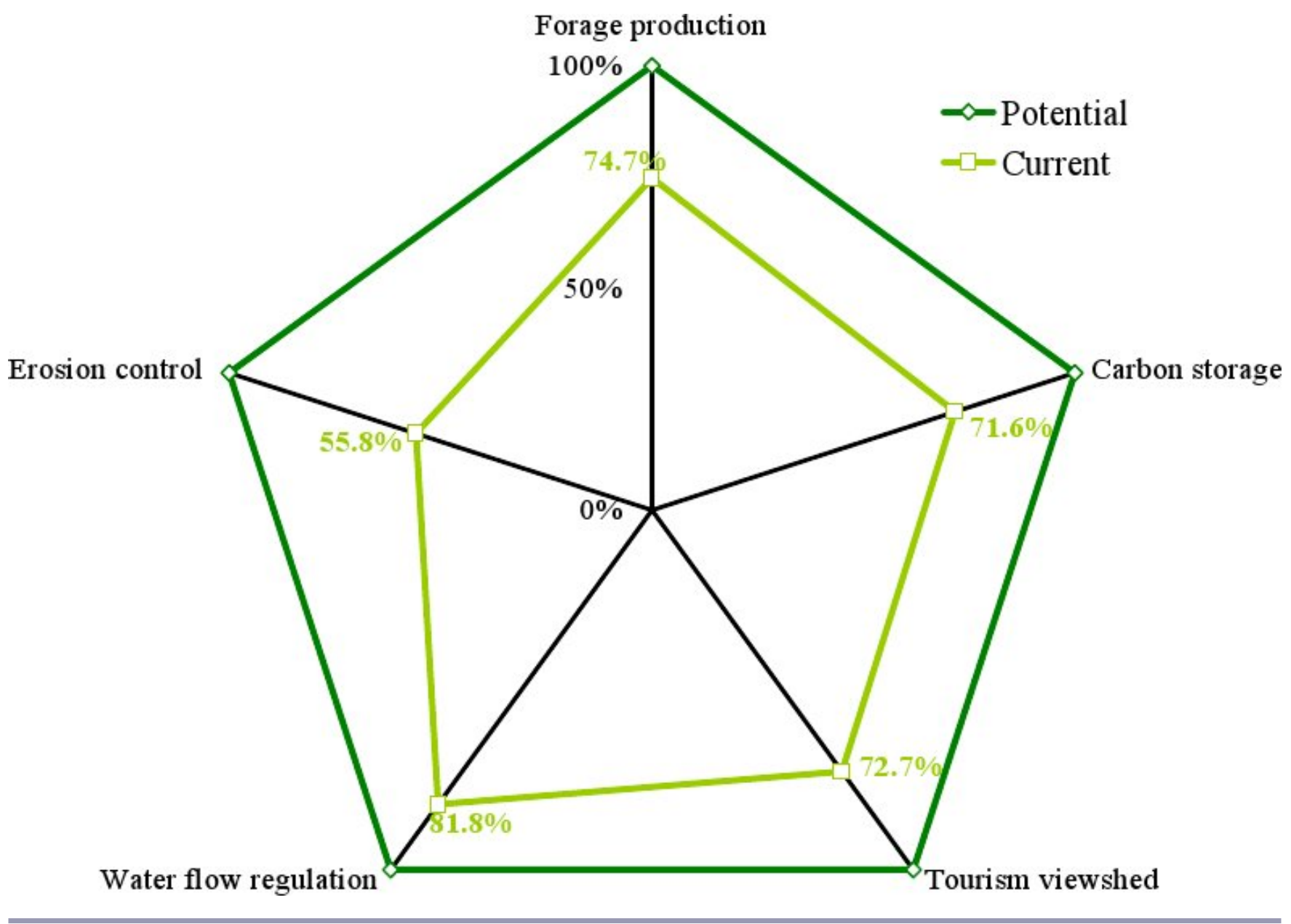

out plants rather than biting off foliage. In addition, trampling and territorial displays lead to soil compaction, the removal of the biological soil crust, and the formation of pathways that channel surface water (Cupido 2005). These impacts, together with the impacts of extensive sheep farming, have resulted in most of the changes in land cover and declines in ecosystem services shown in Fig. 3. Other associated impacts of overgrazing (which include salinization, soil loss, sedimentation, declines in water quality, and reductions in nitrogen input) will further undermine the future productivity of the system.
The history of land-use decisions and their impacts in the Little Karoo point to the need to manage systems in ways that recognize their natural constraints and vulnerabilities, as well as the need to create future economies and livelihoods that foster sustainable use of services along with the promotion of human well-being. Sustainable landuse practices rely on the consideration of, and protection of, ecosystems and their services. Such practices focus on maintaining the resilience of ecosystems, and on building agility into production strategies, enabling responses to market trends and fluctuations. Based on our research, we outline 
below some recommendations aimed at building sustainable landscapes in the Little Karoo.

\section{Building a Sustainable Future: Who Pays?}

Creating a sustainable Little Karoo will require improvements in the current condition of its ecosystems and their services. This, in turn, will require large-scale conservation and restoration activities targeted at areas of importance to waterflow regulation and erosion control (unfortunately these display very little overlap; see Table 1). This realization is not new and, as far back at the 1930s, the government formulated policies to deal with drought and erosion. However, the lack of policy coordination and alignment, the short duration of successful legislation (Beinart 2003, Dean and Roche 2007), and the slow pace of ecosystem recovery, leave the Little Karoo districts as some of the most degraded areas in the Western Cape Province of South Africa (Hoffman and Ashwell 2001).

The global significance of the region's biodiversity, along with its threatened state, have attracted local and international investment in conservation programs, including the establishment of the GI, the development of management guidelines for the ostrich industry, and the establishment of a biodiversity tourist route and catchment management projects. However, the scale of the challenges makes it essential that the efforts extend beyond just the conservation sector to other sectors, landowners, and even new funding mechanisms.

The short-term opportunity costs for farmers, discount rates, and cost of restoration programs (along with their sometimes low likelihood of success) (Wiegand et al. 1995, Herling et al. 2009) make restoration efforts by private landowners currently unfeasible. This echoes the lament of Ruhl et al. (2007) that there are no incentives for rational people to safeguard something they own, because doing so will deliver, in uncertain ways and perhaps only some time in the future, benefits to others who live somewhere else.

An alternative funding mechanism that deserves investigation is the "Payment for Ecosystem Services" (PES). These PES projects have shown some potential in South Africa in public-funded poverty relief programs that clear invasive alien plants and restore hydrological function (Turpie et al. 2008). They have also aided in the design of internationally and nationally funded restoration programs in the Drakensburg mountains (Blignaut et al. 2008). The advent of carbon markets broadens the funding mechanisms available for these schemes, given the high carbon sequestration values in parts of the Little Karoo (Mills et al. 2005), along with the degraded state of its carbon hotspots. However, of note is that areas of carbon storage potential show low levels of overlap with areas important to other ecosystem services (Table 1). Furthermore, as Ruhl et al. (2007) and Blignaut and Aronson (2008) point out, PES schemes require a fundamental shift in the way the existing institutions and legal, policy, and accounting frameworks currently operate. Once we have adopted these (currently radical) shifts, then perhaps restoration of the ecosystems and ecosystem services of the Little Karoo will begin to make sense.

\section{Building a Sustainable Future: Economies of the Future}

In addition to improvements in the current condition of the ecosystems and services of the Little Karoo, alternatives to the current high-density livestock livelihoods will need to be identified and investigated. In assessing alternative land uses, our work has highlighted two characteristics of the region's ecosystem services that might be of use: (1) the key role that water services play in the system, and (2) the potential of carbon storage and tourism for the future economy of the region.

Water-flow regulation is a crucial service in the Little Karoo, with effects that cascade throughout the entire system and its services. It underpins the productivity of the system and determines its vulnerability to future change. The currently degraded state of water services, along with the heavy reliance of current land uses on water, point to a need to consider future land uses that promote efficient water use, and land management that ensures maximum sustained water yields and quality.

Carbon storage and tourism ecosystem services provide opportunities for landowners to diversify their income streams and the potential for them to make money from their land without having to overstock it with ostriches. With regard to stimulating a carbon economy in the region, research is currently underway to assess the carbon 
sequestration rates associated with experimental plantings of spekboom (Portulacaria afra) in a wide range of spekboom-dominated thicket habitats throughout the region. This will assess the extent to which the promising findings regarding the viability of restoration for carbon credits documented by Mills and Cowling (2006) apply throughout the Little Karoo. Excellent progress has been made with developing documentation for participation in the formal carbon market (through the Kyoto Protocol's Clean Development Mechanism [CDM]) in a region that forms the northeastern boundary of the Little Karoo (A. J. Mills, personal communication). Owing to the considerable transaction costs, developing access to the formal and informal carbon markets needs to parallel the ecological research on sequestration rates. There are plans to do precisely this.

Tourism is developing rapidly in the area, and many landowners earn additional income from accommodation and recreation opportunities. Several land purchases in the region over the last 10 years have been made in order to create tourist features such as private luxury game parks (O'Farrell et al. 2008). There are concerns that land managed for tourism is not synonymous with land managed for conservation due to the differences in contractual commitments as well as management regimes. However, several studies highlight the potential that privately owned areas can play in safeguarding ecosystems and their services, especially if partnered with useful information, incentives, and management guidelines (Fitzsimons and Westcott 2008, Gallo et al. 2009).

\section{Building a Sustainable Future: Science in Partnership with Stakeholders}

The path to a sustainable Little Karoo will be a challenging one, requiring changes in land use, policies, behavior, institutions, markets, accounting systems, and incentive schemes. Our results also point to a need for urgent change in current landuse activities if some future options are to be kept open for the region and its people. The required changes would be even more daunting if the stakeholders in the region were neither convinced of the need for change nor in agreement on a way forward. A forum and a social process have been provided through the GI for stakeholders to express their information needs, and for scientists to engage with the stakeholders, respond to their needs, present their work, and discuss its results. Recognizing the importance of socially engaged science (van Kerkhoff and Lebel 2006, Cowling et al. 2008), we feel that this represents an important first step on this path to sustainability. Furthermore, the GI Forum has proved to be a useful method for fostering agreement on the problem to be solved, and promoting co-governance through agency representation on (and learning from) the forum.

Although acknowledging that there will invariably be complexity and uncertainty associated with the study of multiple ecosystem services, we feel that field measurements of the impacts of land-cover change on ecosystem services should be an important focus for the Little Karoo Study Group in the future. Field measurements would allow us to groundtruth expert estimates and extrapolations, as well as fill in the gaps around service flows for urban and cultivated systems. The low certainty attached to carbon storage services makes them a priority, where ongoing and future research will improve certainty in this service, concerning the impacts of degradation on the service and an understanding of how to move from carbon storage to carbon sequestration (Mills and Cowling 2006).

In addition to research into carbon sequestration, new projects have arisen through the GI, the forum, and the study group. One of these aims to convert the information developed in our research into useruseful and user-friendly products (mainstreaming, as exemplified by Pierce et al. 2005) to be distributed to management agencies and landowners in hard copy and over the internet (http://www.gou ritz.com). Another planned project follows the operational framework outlined by Cowling et al. (2008) for mainstreaming and safeguarding ecosystem services and moves forward into the collaborative development of scenarios, strategic objectives, and actions for the Little Karoo.

\section{CONCLUSION}

Safriel et al. (2005) reflect on the historic ability of societies in semiarid systems to cope and adapt to their harsh environment. Social resilience, knowledge evolution, and successful farmer adaptation have played a key role in this ability to cope much better than non-dryland farmers at similar levels of human well-being. This competitive edge, partnered with the significant biodiversity found within semiarid systems, leaves 
Safriel and his colleagues feeling optimistic about the potential for these social-ecological systems to alleviate the current low levels of human well-being. We remain hopeful that the Little Karoo too can follow this course, but acknowledge that the individual, economic, institutional, and political requirements are significant and wide ranging, and for the most part, are not currently in existence.

Responses to this article can be read online at: http://www.ecologyandsociety.org/voll4/iss 1/art38/ responses/

\section{Acknowledgments:}

The Council for Scientific and Industrial Research, the National Research Foundation, the Nelson Mandela Metropolitan University, and the IIASAcoordinated EC project GEO-BENE provided financial support. A. Vlok and the GI Forum are thanked for their interest and support. Three anonymous reviewers are thanked for their insightful and useful comments.

\section{LITERATURE CITED}

Beinart, W. 2003. The rise of conservation in South Africa: settlers, livestock and the environment 1770-1950. Oxford University Press, New York, New York, USA.

Bennett, E. L., and P. Balvanera. 2007. The future of production systems in a globalized world. Frontiers in Ecology and the Environment 5:191198.

Blignaut, J., and J.Aronson. 2008. Getting serious about maintaining biodiversity. Conservation Letters 1:12-17.

Blignaut, J., J. Aronson, M. Mander, and C. Marais. 2008. Investing in natural capital and economic development: South Africa's Drakensberg Mountains. Ecological Restoration 26(2):143-150.

Bohensky, E., B. Reyers, and A. S. van Jaarsveld. 2006. Future ecosystem services in a southern African river basin: reflections on a scenario planning experience. Conservation Biology 20 (4):1051-1061.
Bosch, J. M., and J. D. Hewlett. 1982. A review of catchment experiments to determine the effect of vegetation changes on water yield and evapotranspiration. Journal of Hydrology 55:3-23.

Calder, I. R. 1998. Water use by forests, limits and controls. Tree Physiology 18:625-631.

Chan, K. M. A., M. R. Shaw, D. R. Cameron, E. C. Underwood, and G. C. Daily. 2006. Conservation planning for ecosystem services. PLoS Biology 4 :(11:e379). doi:10.1371/journal. pbio.0040379.

Colding, J., J. Lundberg and C. Folke. 2006. Incorporating green-area user groups in urban ecosystem management. Ambio 35(5):237-244.

Costanza, R., R. d'Arge, R. de Groot, S. Farber, M. Grasso, B. Hannon, K. Limburg, S. Naeem, R. V. O'Neil, J. Paruelo, R. G. Raskin, P. Sutton, and van M. van den Belt. 1997. The value of the world's ecosystem services and natural capital. Nature 387:253-260.

Cowling, R. M., B. Egoh, A. T. Knight, P. J. O'Farrell, B. Reyers, M. Rouget, D. Roux, A. Welz, and A. Wilhelm-Rechman. 2008. An operational model for mainstreaming ecosystem services for implementation. Proceedings of the National Academy of Sciences 105(28):9483-9488.

Cupido, C. F. 2005. Assessment of veld utilisation practices and veld condition in the Little Karoo. Dissertation, University of Stellenbosch, Stellenbosch, South Africa.

De Fries, R. S., J. A. Foley, and G. P. Asner. 2004. Land-use choices: balancing human needs and ecosystem function. Frontiers in Ecology and the Environment 2:249-257.

de Groot, R., M. A. Wilson, and R. M. Boumans. 2002. A typology for the classification, description and valuation of ecosystem functions, goods and services. Ecological Economics 41:393-408.

Dean, W. R. J., and S. J. Milton. 2003. Did the flora match the fauna? Acocks and historical change in Karoo biota. South African Journal of Botany 69:68-78.

Dean, W. R. J., and C. J. Roche. 2007. Setting appropriate targets for changed ecosystems in the semiarid Karoo, South Africa. Pages 57-63 in J. 
Aronson, S. J. Milton, and J. N. Blignaut, editors. Restoring natural capital. science, business, and practice. Island Press, Washington, D.C., USA.

Department of Environmental Affairs and Tourism (DEAT). 2006. A report on the state of the environment. South Africa Environment Outlook. Department of Environmental Affairs and Tourism, Pretoria, South Africa.

Eden District Municipality (EDM). 2008. Revised integrated development plan 2008/2009. [online] URL: http://www.edendm.co.za.

Egoh, B., B. Reyers, M. Rouget, D. M. Richardson, and A. S. van Jaarsveld. 2008. Mapping ecosystem services for planning and management. Agriculture, Ecosystems and Environment 127:135-140.

Environmental Systems Research Institute (ESRI). 2008. ArcGIS Desktop (ArcInfo) Software. ESRI, Redlands, California, USA.

Fitzsimons, J. A., and G. Wescott. 2008. The role of multi-tenure reserve networks in improving reserve design and connectivity. Landscape and Urban Planning 85:163-173.

Foley, J. A., R. DeFries, G. P. Asner, C. Barford, G. Bonan, S. R. Carpenter, F. S. Chapin, M. T. Coe, G. C. Daily, H. K. Gibbs, J. H. Helkowski, T. Holloway, E. A. Howard, C. J. Kucharik, C. Monfreda, J. A. Patz, I. C. Prentice, N. Ramankutty, and P. K. Snyder. 2005. Global consequences of land use. Science 309:570-574.

Gallo, J. A., L. Pasquini, B. Reyers, and R. M. Cowling. 2009. The role of private conservation areas in biodiversity representation and target achievement within the Little Karoo region, South Africa. Biological Conservation 142:446-454.

Hadorn, G. H., D. Bradley, C. Pohl, S. Rist, and U. Wiesmann. 2006. Implications of transdisciplinarity for sustainability research. Ecological Economics 60(1):119-128.

Herling, M. C., C. F. Cupido, P. J. O'Farrell, and L. Du Plessis. 2009. The financial costs of ecologically nonsustainable farming practices in a semiarid system. Restoration Ecology, in press. DOI: 10.1111/j.1526-100X.2008.00419.x
Hoffman M. T., and R. M. Cowling. 1990. Desertification in the lower Sundays River Valley, South Africa. Journal of Arid Environments 19:105117.

Hoffman, T., and A. Ashwell. 2001. Nature divided: land degradation in South Africa. University of Cape Town Press, Cape Town, South Africa.

Kareiva, P., S. Watts, R. McDonald, and T. Boucher. 2007. Domesticated nature: shaping landscapes and ecosystems for human welfare. Science 316:1866-1869.

Knight, A. T., R. M. Cowling, M. Rouget, A. Balmford, A. T. Lombard, and B. M. Campbell. 2008. "Knowing" but not "doing": selecting priority conservation areas and the research-implementation gap. Conservation Biology 22:610-617.

Kreuter, U. P., H. G. Harris, M. D. Matlock, and R. E. Lacey. 2001. Change in ecosystem service values in the San Antonio area, Texas. Ecological Economics 39:333-346.

Le Maitre, D. C., and P. J. O'Farrell. 2008. Social-ecological resilience in a dry environment: people and water resources in the Little Karoo. Pages 339-382 in M. Burns and A. Weaver, editors. Exploring sustainability science-a Southern African perspective. Sun Media, Stellenbosch, South Africa.

Le Maitre, D. C., S. J. Milton, C. Jarmain, C. A. Colvin, I. Saayman, and J. H. J. Vlok. 2007. Landscape-scale hydrology of the Little Karoo: linking ecosystems, ecosystem services and water resources. Frontiers in Ecology and the Environment 5:261-270.

Levy, M., S. Babu, K. Hamilton, V. Rhoe, A. Catenazzi, M. Chen, W. V. Reid, D. Sengupta, C. Ximing, A. Balmford, and W. Bond. 2005. Ecosystem conditions and human well-being. Pages 125-164 in R. Hassan, R. J. Scholes, and N. Ash, editors. Ecosystems and human well-being. Volume 1. Findings of the Conditions and Trends Working Group of the Millennium Ecosystem Assessment. Island Press, Washington, D.C., USA.

Li, R.-Q., M. Dong, J.-Y. Cui, L.-L. Zhang, Q.G. Cui, and W.-M. He. 2007. Quantification of the impact of land-use changes on ecosystem services: 
a case study in Pingbian County, China. Environmental Monitoring and Assessment 128:503-510.

Max-Neef, M. A. 2005. Foundations of transdisciplinarity. Ecological Economics 53:5-16.

Mills, A. J., and R. M. Cowling. 2006. Rate of carbon sequestration at two thicket restoration sites in the Eastern Cape, South Africa. Restoration Ecology 14:38-49.

Mills, A. J., R. M. Cowling, M. V. Fey, G. I. H. Kerley, J. S. Donaldson, R. G. Lechmere-Oertel, A. M. Sigwela, A. L. Skowno, and P. Rundel. 2005. Effects of goat pastoralism on ecosystem carbon storage in semiarid thicket, Eastern Cape, South Africa. Austral Ecology 30:797-804.

Millennium Ecosystem Assessment (MA). 2003. Ecosystems and human well-being: a frameworkfor assessment. Island Press, Washington, D.C., USA.

Millennium Ecosystem Assessment (MA). 2005. Millennium ecosystem assessment synthesis report. Island Press, Washington, D.C., USA.

Mitchell, C. A., A. L. Carew, and R. Clift. 2004. The role of the professional engineer and scientist in sustainable development. Pages 29-56 in A. Azapagig, S. Perdan, and R. Clift, editors. Sustainable development in practice: case studies for engineers and scientists. Wiley, Chichester, UK.

Mittermeier, R. A., M. Hoffmann, J. D. Pilgrim, T. B. Brooks, C. G. Mittermeier, J. L. Lamoreux, and G. Fonseca., editors. 2005. Hotspots revisited: earth's biologically richest and most endangered ecoregions. Cemex, Mexico City, Mexico.

O'Farrell, P. J., J. S. Donaldson, and M. T. Hoffman. 2007. The influence of ecosystem goods and services on livestock management practices on the Bokkeveld plateau, South Africa. Agriculture, Ecosystem and Environment 122:312-324.

O'Farrell, P. J., D. C. Le Maitre, C. Gelderblom, D. Bonora, T. Hoffman and B. Reyers. 2008. Applying a resilience framework in the pursuit of sustainable land-use development in the Little Karoo, South Africa. Pages 383-430 in M. E. Burns, and A. v. B. Weaver, editors. Exploring sustainability science - a Southern African perspective. Sun Press, Stellenbosch, South Africa.
Pereira, H. M., B. Reyers, M. Watanabe, E. Bohensky, S. Foale, C. Palm, V. Espaldon, D. Armenteras, M. Tapia, A. Rincon, M. Lee, A. Patwardhan, and I. Gomes. 2005. Condition and trends of ecosystem services and biodiversity. Pages 87-117 in D. Capistrano, C. Samper, M. J. Lee, and C. Raudsepp-Hearne, editors. Ecosystems and human well-being: multi scale assessments. Volume 4. Findings of the Sub-global Assessments Working Group of the Millennium Ecosystem Assessment. Island Press, Washington, D.C., USA.

Pierce, S. M., R. M. Cowling, A. T. Knight, A. T. Lombard, M. Rouget, and T. Wolf. 2005. Systematic conservation assessment products for land use planning: interpretation for implementation. Biological Conservation 125:441-548.

Prendergast, J. R., R. M. Quinn, J. H. Lawton, B. C. Eversham, and D. W. Gibbons. 1993. Rare species, the coincidence of diversity hot spots and conservation strategies. Nature 356:335-337.

Priess J. A., M. Mimler, A. Klein, S. Schwarze, T. Tscharntke, and I. Steffan-Dewenter. 2007. Linking deforestation scenarios to pollination services and economic returns in coffee agroforestry systems. Ecological Applications 17(2):407-417.

Rodríguez, J. P., T. D. Beard, Jr., E. M. Bennett, G. Cumming, S. Cork, J. Agard, A. P. Dobson, and G. D. Peterson. 2006. Trade-offs across space, time, and ecosystem services. Ecology and Society 11(1): 28. [online] URL: http://www.ecologyandso ciety.org/vol11/iss1/art28/.

Rouget, M., R. M. Cowling, J. H. J. Vlok, M. Thompson, and A. Balmford. 2006. Getting the biodiversity intactness index right: the importance of habitat degradation data. Global Change Biology 12:2032-2036.

Ruhl, B., S. E. Kraft, and C. L. Lant. 2007. The law and policy of ecosystem services. Island Press, Washington, D.C., USA.

Safriel, U., Z. Adeel, D. Niemeijer, J. Puigdefabregas, R. White, R. Lal, M. Winslow, J.Ziedler,S. Prince, E.Archer, and C. King. 2005. Dryland systems. Pages 623-662 in R. Hassan, R. J. Scholes, and N. Ash, editors. Ecosystems and human well-being. Volume 1. Findings of the Conditions and Trends Working Group of the 
Millennium Ecosystem Assessment. Island Press, Washington, D.C., USA.

Scholes, R. J., and R. Biggs. 2005. A biodiversity intactness index. Nature 434:45-49.

Swinton, S. M., F. Lupi, G. P. Robertson, and S. K. Hamilton. 2007. Ecosystem services and agriculture: cultivating agricultural ecosystems for diverse benefits. Ecological Economics 64(2):245252.

Thompson, M., J. H. J. Vlok, M. Rouget, M. T. Hoffman, A. Balmford, and R. M. Cowling. 2009. Mapping land transformation in a heterogeneous environment: a rapid and cost effective approach for assessment and monitoring. Journal of Environmental Management, in press.

Turner, B.L. II, P. A. Matson, J. McCarthy, R. W. Corell, L. Christensen, N. Eckley, G. K. Hovelsrud-Broda, J. X. Kasperson, R. E. Kasperson, A. Luers, M. L. Martello, S. Mathiesen, R. Naylor, C. Polsky, A. Pulsipher, A. Schiller, H. Selink, and N. Tyler. 2003. Illustrating the coupled human-environment system for vulnerability analysis: three case studies. Proceedings of the National Academy of Sciences 100:8080-8085.

Turpie, J. K., C. Marais, and J. Blignaut. 2008. The working for water programme: evolution of a payments for ecosystem services mechanism that addresses both poverty and ecosystem service delivery in South Africa. Ecological Economics 65:788-798.

van Jaarsveld, A. S., R. Biggs, R. J. Scholes, E. Bohensky, B. Reyers, T. Lynam, C. Musvoto, and C. Fabricius. 2005. Measuring conditions and trends in ecosystem services at multiple scales: the Southern African Millennium Ecosystem Assessment (SAfMA) experience. Philosophical Transactions of the Royal Society B 360:425-441.

van Kerkhof, L., and Lebel, L. 2006. Linking knowledge and action for sustainable development. Annual Review of Environment and Resources 31:445-477.

Viglizzo, F., and F. C. Frank. 2006. Land-use options for Del Plata Basin in South America: tradeoffs analysis based on ecosystem service provision. Ecological Economics 57:140-151.
Vitousek, P. M., H. A. Mooney, J. Lubechenco, and J. M. Melillo. 1997. Human domination of earth's ecosystems. Science 277:494-499.

Vlok, J. H. J., R. M. Cowling, and T. Wolf. 2005. A vegetation map for the Little Karoo. Unpublished Maps and Report for a SKEP Project Supported by Grant No. 1064410304. Critical Ecosystem Partnership Fund, Cape Town, South Africa. [online] URL: http://bgis.sanbi.org/littlekaroo/index. asp.

Wiegand, T., S. J. Milton, and C. Wissel. 1995. A simulation model for a shrub ecosystem in the semiarid Karoo, South Africa. Ecology 76:2205-2211.

Yadav, V., and G. Malanson. 2008. Spatially explicit historical land use land cover and soil organic carbon transformations in Southern Illinois. Agriculture, Ecosystems and Environment 123:280 292.

Zhao, B., U. Kreuter, B. Li, Z. Ma, J. Chen, and N. Nakagoshi. 2004. An ecosystem service value assessment of land-use change on Chongming Island, China. Land Use Policy 21:139-148. 
APPENDIX 1. Methods and data used to map ecosystem services.

\section{Potential forage production}

Carrying capacities for domestic stock, expressed as number of ha required per large stock unit (LSU), were determined for pristine examples of the 32 habitat types defined in Vlok et al. (2005). This service was mapped by overlaying the carrying capacity recommendation map of the Department of Agriculture (DA) with those of the habitat map prepared by Vlok et al. (2005) for the Little Karoo domain. It is important to note that not all habitat types of the Little Karoo are covered by the DA map; however it does provide clear recommendations for the habitat types with the highest (valley thicket with spekboom) and lowest (Proteoid fynbos) carrying capacity, as well as several other clear recommendations at other carrying capacities (e.g., for Apronveld, Gannaveld, and Sandolienveld). For habitat units not recognized by the DA map, carrying capacity recommendations for pristine examples of such types had to be interpolated. This was done by estimating the degree to which plants palatable to domestic stock would increase or decrease in the habitat type in relation to the DA recommendation for the most similar habitat type. These estimates were reviewed in terms of the range recommended by the DA, as well as by officers from the DA. We assigned a medium level of certainty to these reviewed and well understood data.

\section{Potential carbon storage}

Carbon storage refers to the number of tons of carbon locked up in the above and below ground biomass of plants; most of this carbon would be released if these intact ecosystems were transformed or degraded. In mapping this service, we (similar to Chan et al. 2006), focused on carbon storage rather than sequestration as an ecosystem service, mostly because of the data gaps and uncertainty in estimating sequestration. Most Little Karoo habitat types were assigned zero carbon storage values due to their arid, fire prone nature. For the remainder, carbon storage values were extracted for the habitat types of arid thicket with spekboom based on research on carbon storage in the region (Mills et al. 2005, Mills and Cowling 2006). Through a process of expert consultation, the more mesic thicket with spekboom types were assigned higher values based on higher predicted biomass. Similarly, arid thicket types without spekboom (Portulacaria afra) were assigned lower values owing to the large contribution of this species to carbon stocks (Mills et al. 2005). Three remaining habitat types (Randteveld, Gravel Apronveld, and Thicket Mosaics) were assigned small values to reflect the small amount of carbon they potentially store. The ecosystem service was mapped as tons of carbon stored per ha per habitat type. We assigned a high certainty to the carbon storage values of the arid thicket with spekboom type, and low certainties to the remaining values where scientific understanding is still in development.

\section{Potential erosion control}

In mapping this ecosystem service, we assessed the interaction between rainfall, soil depth and texture for each habitat type. This information was used to assign habitat types to classes of high, medium, and low erosion hazard. These classes were determined using the vegetation descriptions in Vlok et al. (2005) and through expert consultation. We identified high erosion hazard habitat types as all of those belonging to the aquatic source (streams and seepage areas) and drainage (river and floodplains) biomes, as well as the Gannaveld types which are located in valley bottoms and often form large open plains just above the river and floodplain habitat type. Gannaveld types have deep, fine-fractured soils very prone to erosion, with rainstorms transferring soils to the riverine and floodplain habitats causing declines in water quality and nutrient enrichment. These habitat types are associated with high runoff (high rainfall mountain catchment areas) and high run on areas (lowlands with vulnerable soils plus other functions (e. g. nutrient retention)) and are areas where the maintenance of pristine vegetation cover is essential. These areas form the focus of this study. Areas of medium hazard include the remaining mesic and montane habitat types, which are important for water run-off and drainage. We assigned a high certainty to these qualitative ranks based on a sound expert understanding of the service.

\section{Potential water-flow regulation}

In mapping this service, we used data on both water-flow regulation and water-quality regulation. The 
former is a function of how much water infiltrates the soil, passes beyond the root zone, and recharges the groundwater stored in the catchment (Sandström 1998). Infiltration is primarily regulated by the texture of the soils (rapid in sandy soils and slow in clays) and inputs from the vegetation and fauna which maintain the soil porosity and protect it from the erosive forces of raindrops and unhindered surface run-off (Dean 1992, Bruijnzeel 2004, Ludwig et al. 1997). From the human use perspective, the most important component of the water flows is the sustained flows which meet needs in the dry season and also increase yields from storage dams. One measure of sustained flows is the river baseflow which is the main component of the flow during the dry season and is typically generated by groundwater discharge (Farvolden 1963). The most appropriate dataset for estimating these flows was gridded data on groundwater recharge extracted from the Department of Water Affairs and Forestry (DWAF 2005). This estimate combines data on rainfall, geology (lithology), and estimates of recharge (e.g., from chloride profiles) to provide a grid on recharge depth at a $1 \mathrm{~km} \times 1 \mathrm{~km}$ resolution. These estimates take into account losses due to evaporation from the soil, interception, and transpiration of soil water by plants (i.e., green water), but not the losses during the groundwater discharge into rivers (e.g., through riparian vegetation).

In mapping the water-quality component of the service, we used data on the relationship between geology (primary lithology) and groundwater-quality (electrical conductivity) because high sodium chloride (salinity) concentrations make the water unfit for domestic use. Data on groundwater-quality were extracted from borehole water analyses stored in the Water Management System database of the Department of Water Affairs and Forestry. The results were summarized by the primary lithology taken from the 1:1 million geological data (Council for Geosciences 1997). Formations where the electrical conductivity exceeded the target water-quality range for acceptability for domestic water supplies (DWAF 1996) were used to identify and exclude areas where water-quality was deemed unacceptable for domestic consumption. We assigned a high certainty to these well understood and peer-reviewed data.

\section{Potential tourism}

Using ArcGIS 9.2 (ESRI 2008), we modelled a $10 \mathrm{~km}$ viewshed of the major tourist routes of the Little Karoo. The distance was determined based on visual assessments in the region. This viewshed was extracted and used as the ecosystem service of tourism. We assigned a medium level of certainty to these data due to our limited understanding of the full suite of drivers of tourism in the region.

\section{LITERATURE CITED}

Bruijnzeel, L. A. 2004. Hydrological functions of tropical forests: not seeing the soil for the trees? Agriculture, Ecosystems and Environment 104:185-228.

Chan, K. M. A., M. R. Shaw, D. R. Cameron, E. C. Underwood, and G. C. Daily. 2006. Conservation planning for ecosystem services. PLoS Biology 4 (11:e379). doi:10.1371/journal. pbio.0040379.

Council for Geosciences. 1997. 1:1 000000 scale geological map of the Republic of South Africa and the Kingdoms of Lesotho and Swaziland. Council for Geoscience, Pretoria, South Africa.

Dean, W. R. J. 1992. Effects of animal activity on the absorption rate of soils in the southern Karoo, South Africa. Journal of the Grassland Society of Southern Africa 9:178-180.

Department of Water Affairs and Forestry (DWAF). 1996. South African water quality guidelines: domestic water use. 2nd edition, volume 1. Department of Water Affairs and Forestry, Pretoria, South Africa.

Department of Water Affairs and Forestry(DWAF). 2005. Groundwater resource assessment, phase 
II, methodology: groundwater-surface water interactions. Department of Water Affairs and Forestry, Pretoria, South Africa. [online] URL: http://www.dwaf.gov.za/ Geohydrology/gra2/3aEFinalReportA. pdf.

Environmental Systems Research Institute (ESRI). 2008. ArcGIS Desktop (ArcInfo) Software. ESRI, California, USA.

Farvolden, R. N. 1963. Geologic controls on ground-water storage and base flow. Journal of Hydrology 1:219-249.

Ludwig, J. A., D. J. Tongway, D. O. Freudenberger, J.C. Noble, and K. C. Hodgkinson, editors. 1997. Landscape ecology, function and management: principles from Australia's rangelands. CSIRO, Melbourne, Australia.

Mills, A. J., and R. M. Cowling. 2006. Rate of carbon sequestration at two thicket restoration sites in the Eastern Cape, South Africa. Restoration Ecology 14:38-49.

Mills, A. J., R. M. Cowling, M. V. Fey, G. I. H. Kerley, J. S. Donaldson, R. G. Lechmere-Oertel, A. M. Sigwela, A. L. Skowno, and P. Rundel. 2005. Effects of goat pastoralism on ecosystem carbon storage in semiarid thicket, Eastern Cape, South Africa. Austral Ecology 30:797-804.

Sandström, K. 1998. Can forests 'provide' water: widespread myth or scientific reality? Ambio 27:132138.

Vlok, J. H. J., R. M. Cowling, and T. Wolf. 2005. A vegetation map for the Little Karoo. Unpublished Maps and Report for a SKEP project

Supported by Grant No 1064410304. Critical Ecosystem Partnership Fund. Cape Town, South Africa. [online] URL: http://bgis.sanbi.org/littlekaroo/index.asp. 
APPENDIX 2. Ecosystem service values per habitat type for each state of land-cover.

\begin{tabular}{|c|c|c|c|c|c|c|}
\hline \multirow[b]{2}{*}{ Habitat type } & \multicolumn{3}{|c|}{ Forage production (ha/LSU) } & \multicolumn{3}{|c|}{ Carbon storage (tons/ha) } \\
\hline & Pristine & $\begin{array}{l}\text { Moderately } \\
\text { degraded }\end{array}$ & $\begin{array}{l}\text { Severely } \\
\text { degraded }\end{array}$ & Pristine & $\begin{array}{l}\text { Moderately } \\
\text { degraded }\end{array}$ & $\begin{array}{l}\text { Severely } \\
\text { degraded }\end{array}$ \\
\hline $\begin{array}{l}\text { Freshwater stream \& seepage } \\
\text { areas }\end{array}$ & 140 & 180 & 210 & 0 & 0 & 0 \\
\hline River \& floodplain & 60 & 80 & 120 & 0 & 0 & 0 \\
\hline Apronveld & 54 & 70 & 90 & 0 & 0 & 0 \\
\hline Arid Proteoid & 140 & 180 & 210 & 0 & 0 & 0 \\
\hline Arid Renosterveld & 108 & 140 & 160 & 0 & 0 & 0 \\
\hline Arid Renosterveld Mosaics & 72 & 95 & 110 & 0 & 0 & 0 \\
\hline Arid Thicket Mosaics & 75 & 90 & 100 & 120 & 100 & 80 \\
\hline Arid Thicket with Spekboom & 66 & 85 & 100 & 200 & 150 & 100 \\
\hline $\begin{array}{l}\text { Arid Thicket with Spekboom } \\
\text { Mosaics }\end{array}$ & 70 & 90 & 100 & 200 & 150 & 100 \\
\hline Asbosveld & 72 & 90 & 110 & 0 & 0 & 0 \\
\hline Asteraceous & 108 & 120 & 160 & 0 & 0 & 0 \\
\hline Ericaceous & 140 & 180 & 210 & 0 & 0 & 0 \\
\hline Gannaveld & 60 & 85 & 110 & 0 & 0 & 0 \\
\hline Grassy & 60 & 90 & 105 & 0 & 0 & 0 \\
\hline Gravel Apronveld & 72 & 95 & 105 & 20 & 10 & 5 \\
\hline Kalkveld & 54 & 80 & 95 & 0 & 0 & 0 \\
\hline Mesic Proteoid & 140 & 180 & 210 & 0 & 0 & 0 \\
\hline Mesic Renosterveld & 60 & 85 & 110 & 0 & 0 & 0 \\
\hline Mesic Renosterveld Mosaics & 60 & 85 & 110 & 0 & 0 & 0 \\
\hline Quartz Apronveld & 65 & 80 & 90 & 0 & 0 & 0 \\
\hline Quartz Asbosveld & 72 & 90 & 110 & 0 & 0 & 0 \\
\hline Quartz Gannaveld & 60 & 85 & 110 & 0 & 0 & 0 \\
\hline Randteveld & 80 & 95 & 120 & 30 & 15 & 5 \\
\hline
\end{tabular}




\begin{tabular}{|c|c|c|c|c|c|c|}
\hline Restioid & 108 & 120 & 160 & 0 & 0 & 0 \\
\hline Sandolien & 72 & 95 & 120 & 0 & 0 & 0 \\
\hline Scholtzbosveld & 72 & 95 & 110 & 0 & 0 & 0 \\
\hline Subalpine & 140 & 180 & 210 & 0 & 0 & 0 \\
\hline Thicket Mosaics & 72 & 90 & 110 & 50 & 40 & 30 \\
\hline Valley Thicket Mosaics & 60 & 80 & 100 & 150 & 120 & 100 \\
\hline Valley Thicket with Spekboom & 48 & 70 & 80 & 250 & 180 & 120 \\
\hline $\begin{array}{l}\text { Valley Thicket with Spekboom } \\
\text { Mosaics }\end{array}$ & 55 & 75 & 90 & 250 & 180 & 120 \\
\hline Waboomveld & 60 & 90 & 105 & 0 & 0 & 0 \\
\hline
\end{tabular}

Note: Converted areas are assumed to produce none of the ecosystem service and thus the fourth class of land-cover, transformed, is not shown here. 
APPENDIX 3. Reduction in water-flow regulation for each biome per land-cover category.

\begin{tabular}{lccc}
\hline \hline Biome & \multicolumn{3}{c}{ \% Reductions in groundwater recharge } \\
\cline { 2 - 4 } & Pristine & Moderately degraded & Severely degraded \\
\hline Fynbos & & 0 & 0 \\
Renosterveld & 0 & 10 & 50 \\
Succulent Karoo & 0 & 10 & 50 \\
Subtropical Thicket & 0 & 10 & 50 \\
Aquatic (Drain \& Source) & 0 & 10 & 50 \\
\hline
\end{tabular}

Note: Converted areas are assumed to produce none of the ecosystem service and thus the fourth class of land-cover, transformed, is not shown here. 